\title{
Effects of hypo-osmosis on the coral Stylophora pistillata: nature and cause of 'low-salinity bleaching'
}

\author{
Ailsa P. Kerswell ${ }^{1,2, *}$, Ross J. Jones ${ }^{1}$ \\ ${ }^{1}$ Centre for Marine Studies, The University of Queensland, St Lucia, Queensland 4072, Australia \\ ${ }^{2}$ Present address: School of Marine Biology and Aquaculture, James Cook University, Townsville, Queensland 4811, Australia
}

\begin{abstract}
The response of the scleractinian coral Stylophora pistillata to short-term (min to h) and long-term (d) exposure to reduced-salinity seawater was examined. Pulse Amplitude Modulated (PAM) chlorophyll fluorescence techniques were used to assess the photosynthetic efficiency of the symbiotic dinoflagellates (dark-adapted $F_{\mathrm{v}} / F_{\mathrm{m}}$ ) in the coral tissues (in hospite) before, during and after exposure. Exposure to reduced-salinity seawater caused a marked reduction in efficiency (the ratio of variable $\left[F_{\mathrm{v}}\right]$ to maximal $\left[F_{\mathrm{m}}\right]$ fluorescence), and there was an apparent link between a reduction in dark-adapted $F_{\mathrm{v}} / F_{\mathrm{m}}$ and a loss of symbiotic dinoflagellates from the corals. The reduction in $F_{\mathrm{v}} / F_{\mathrm{m}}$ of the symbiotic algae and subsequent dissociation of the coral-algal symbiosis (coral bleaching) occurred during exposure to reduced-salinity seawater in either the light or dark. The results demonstrate that bleaching in response to low-salinity seawater is a truly sublethal response, contrary to a recent suggestion. The study also suggests that bleaching of corals in response to low-salinity seawater may not involve the passive loss of algal symbionts and that an impairment of the capacity of the algal symbionts for photosynthesis represents a common 'cue' initiating the dissociation of the coral-algal symbiosis during exposure to sub-optimal conditions. This study demonstrates how exposure to low-salinity seawater alone can cause some of the symptoms commonly attributed to temperature anomalies and anthropogenic pressures on coral reefs.
\end{abstract}

KEY WORDS: Coral bleaching $\cdot$ Symbiotic dinoflagellates $\cdot$ Salinity $\cdot$ Chlorophyll fluorescence

\section{INTRODUCTION}

Coral reefs are generally considered to exist in areas where salinity is stable over long timescales (Coles \& Jokiel 1992). Nevertheless, major rainfall events are common in tropical regions, and during such episodes corals may experience significant reductions in salinity. In the short term (min to h), decreases in salinity levels can occur in shallow reef areas following the coincidence of heavy rainfall with low tides. Over longer periods (i.e. d to wk), salinity levels may be lowered when reefs are inundated by flood plumes of coastal rivers.

Numerous studies have documented short- and longterm reductions in salinity on coral reefs (reviewed in Coles \& Jokiel 1992). For example, Orr \& Moorhouse (1933) recorded a salinity level of $17 \mathrm{ppt}$ in a shallow tide pool on the reef flat at Low Isles (Great Barrier Reef) during the 1928-1929 Great Barrier Reef Expedition. Moberg et al. (1997) recorded a salinity level of $10 \mathrm{ppt}$ in coral-containing tidal pools on the reefs of the inner Gulf of Thailand. Cloud (1952) recorded a salinity level of 4 ppt on a reef flat in Kiribati (formerly the Gilbert Islands, Central Pacific Basin) for the duration of low tide following heavy rains. Salinity levels returned to normal on the following high tide. Over longer periods, Goodbody (1961) reported that heavy rainfall and coastal runoff reduced surface salinity levels in the inshore waters of Jamaica to 5.4 ppt during 1958, and it was 3 mo until all affected areas returned to normal levels of salinity. Goreau (1964) also reported markedly reduced seawater salinity in coastal areas of Jamaica following Hurricane Flora. On the Great Barrier Reef plumes of reduced salinity seawater have been reported to persist for up to $3 \mathrm{wk}$ following cyclones (Van Woesik et al. 1995, Devlin et al. 1998). Berkelmans \& Oliver (1999) 
reported that salinity levels in Cleveland Bay (inner, central Great Barrier Reef) were reduced to 28-32 ppt for $4 \mathrm{wk}$ following heavy rain.

Many studies report the appearance of discoloured or white corals and anemones after exposure to flood waters (Goreau 1964, Egana \& DiSalvo 1982, Engebretson \& Martin 1994, Van Woesik et al. 1995). Both Goreau (1964) and Van Woesik et al. (1995) report striking cutoffs between discoloured and normally pigmented corals coinciding with the depth to which floodwaters penetrated. Laboratory-based studies have also confirmed that corals discolour during exposure to low-salinity seawater (Marcus \& Thorhaug 1981, Coles 1992, Titlyanov et al. 2000). Discolouration of the corals in these studies has traditionally been interpreted as 'coral bleaching', i.e. a sublethal response of corals involving loss of endosymbiotic dinoflagellate microalgae from the coral tissues and/or loss of the pigments of the algae (Fitt et al. 2001). However, an alternative viewpoint has been suggested. Corals that have recently died, leaving only a white calcium carbonate skeleton, superficially resemble heavily bleached corals. This has led to the suggestion that corals exposed to low-salinity seawater do not bleach but rather die, leaving tissue-free skeletons that are mistaken for live corals that have lost their symbiotic algae (HoeghGuldberg 1999). This suggestion adds some confusion as to the nature of the relationship between exposure to low-salinity seawater and coral bleaching.

Corals are osmoconformers, rapidly absorbing water to become iso-osmotic with their surroundings (Rankin \& Davenport 1981). Since water movement is faster than salt diffusion, osmoconformers gain water upon contact with low-salinity water (Rankin \& Davenport 1981). This may result in damage to the animal tissue. On the Great Barrier Reef, Van Woesik et al. (1995) observed tissue swelling and damage to colonies of Acropora formosa exposed to floodwater of the Fitzroy River. Tissue necrosis has also been observed in anemones exposed to reduced salinity (Engebretson \& Martin 1994). Host cells, still containing symbiotic algae, have been observed released from Stylophora pistillata after hypo-osmotic shock (Titlyanov et al. 2000). These authors suggest that the animal host is primarily affected by reductions in salinity.

Marine algae are also affected by reduced salinity. In seaweeds, hypo-osmotic stress causes increases in cell volume and turgor, resulting in the loss of ions and organic solutes as well as damage to membranes and organelles, culminating in cell rupture (Lobban \& Harrison 1994). Damage to cellular structures will inevitably disrupt metabolic function, and changes in ion concentrations may have an inhibitory effect on enzymes systems (Lobban \& Harrison 1994). A number of reports have described a reduction in the photo- synthetic rate of symbiotic dinoflagellates in hospite following exposure to reduced-salinity seawater (Muthiga \& Szmant 1987, Moberg et al. 1997, FerrierPages et al. 1999). Sakami (2000) has found that low salinity causes a reduction in photosynthetic activity in isolated symbiotic dinoflagellates (in vitro). Muthiga \& Szmant (1987) and Moberg et al. (1997) suggest that the observed reduction in photosynthesis may have been due to cellular damage to the algae.

Bleaching of corals in response to low-salinity seawater is the second most commonly cited cause of coral bleaching (Glynn 1991). Despite this, there is no consensus as to the mechanism associated with reducedsalinity bleaching. In contrast, the mechanism associated with the bleaching of corals in response to warm water (the most common form of bleaching) is gradually being elucidated. Numerous studies, using photorespirometry and chlorophyll fluorescence techniques, have now suggested that an impairment of photosynthesis of the algal symbionts is an important component of the bleaching response (Iglesias-Prieto et al. 1992, Jones et al. 1998, Warner et al. 1999). The in vitro and in vivo studies with chlorophyll fluorescence techniques have been particularly informative. One of the most useful chlorophyll fluorescence parameters that can be measured is the ratio of variable $\left(F_{\mathrm{v}}\right)$ to maximal fluorescence $\left(F_{\mathrm{m}}\right) . F_{\mathrm{v}}=F_{\mathrm{m}}-F_{\mathrm{o}}$, where $F_{\mathrm{o}}$ is the initial fluorescence when all reaction centres in Photosystem II (PSII) are open, and $F_{\mathrm{m}}$ is the maximal fluorescence determined after the application of a saturating pulse of white light, i.e. when all PSII reaction centres are closed. When determined in a dark-adapted state, the ratio $F_{\mathrm{v}} / F_{\mathrm{m}}$ is a measure of the maximum potential quantum yield of PSII and changes in $F_{\mathrm{v}} / F_{\mathrm{m}}$ can be used to evaluate reductions of PSII activity caused by acute stress (Schreiber et al. 1986, Krause \& Weis 1991). Marked long-term reduction in $F_{\mathrm{v}} / F_{\mathrm{m}}$ in symbiotic algae of corals in hospite appears to precede the dissociation of the coral-algal symbiosis. This has been observed in response to many stressors, and led to the suggestion that impairment of algal photosynthesis may be a cue (universal) initiating the dissociation of the coral-algal symbiosis (i.e. bleaching) (Jones et al. 1999).

How bleaching in response to reduced-salinity seawater fits into this model is unclear. Certain studies have highlighted damage to the animal host (Engebretson \& Martin 1994, Titlyanov et al. 2000) whilst other studies report impairment of the algae (measured as marked reductions in photosynthetic rates) (Ferrier-Pages et al. 1999, Sakami 2000). In this study, we explore the nature and cause of freshwater bleaching of corals. Firstly, we address the issue of whether the discolouration of corals following exposure to reduced-salinity seawater is in fact coral bleaching, as 
opposed to coral death (Hoegh-Guldberg 1999). Secondly, using chlorophyll fluorescence techniques, we examine the relationship between the impairment of algal photosynthesis and the dissociation of the coralalgal symbiosis in Stylophora pistillata subjected to short- and longer-term reductions in seawater salinity.

\section{MATERIALS AND METHODS}

Coral collection and preparation. All experiments were conducted with the coral Stylophora pistillata (Esper 1797) collected from Heron Reef $\left(23^{\circ} 26^{\prime} \mathrm{S}\right.$, $\left.151^{\circ} 55^{\prime} \mathrm{E}\right)$ in the Capricorn-Bunker Group of reefs in the southern Great Barrier Reef, Australia. Corals were collected from the protected intertidal reef flat at a depth of $<1 \mathrm{~m}$ (MLWS). Small ( $40 \mathrm{~mm}$ long), vertically oriented fragments of $S$. pistillata were isolated from the centre of parent colonies ( 2 explants per colony) using surgical bone forceps. Branch fragments were returned to a $500 \mathrm{l}$ flow-through holding/observation tank at the Heron Island Research Station (HIRS) and mounted into plastic holders with non-toxic modelling clay. Corals were left to recover from the handling procedures for $24 \mathrm{~h}$ before experimentation.

All experiments were conducted under natural light conditions. Photosynthetically Active Radiation (PAR, 400 to $700 \mathrm{~nm}$ ) was measured using a cosine-corrected photosynthetic irradiance sensor, and mean PAR over 10 min intervals was recorded onto a waterproof 392 data recorder (Dataflow Systems). Light recorders were calibrated against a LI-190SA quantum sensor (LI-COR). Water temperature $\left({ }^{\circ} \mathrm{C}\right.$ ) was recorded with an Optical Stowaway ${ }^{\circledR}$ temperature logger (Onset computer Corporation, accuracy $\pm 0.1^{\circ} \mathrm{C}$ ) calibrated against a NATA-certified (National Association of Testing Authorities, NSW, Australia) thermometer. Salinities were measured using a hand-held refractometer (ATAGO, accuracy $\pm 0.5 \mathrm{ppt}$ ).

For each experiment, solutions of the necessary salinity were made by diluting water from the seawater system at HIRS (37 ppt drawn from a subtidal inlet at $6 \mathrm{~m}$ depth on the protected reef slope) with distilled water (MilliQ). Fresh solutions were made immediately before each experiment. To minimise temperature fluctuations, all experiments were conducted in 20 l aquaria semi-submerged within the holding/ observation tank (water bath) receiving a continuous supply of seawater. This minimised temperature fluctuations to $<2^{\circ} \mathrm{C}$ and water temperatures during experiments did not rise above $26^{\circ} \mathrm{C}$. Corals were incubated in $5 \mathrm{l}$ of water during static test conditions and stirring within the containers was achieved using miniature submersible aquarium pumps (Mini-Pro). Evaporation was negligible over a $12 \mathrm{~h}$ period, and salinities did not deviate more than $0.5 \mathrm{ppt}$ over the exposure time. After exposure, corals were returned to the holding/observation tank for an observation period.

Chlorophyll fluorescence measurements. Chlorophyll fluorescence parameters were measured using Pulse Amplitude Modulated (PAM) chlorophyll fluorometry (DIVING-PAM, Walz; Schreiber et al. 1986). Where necessary, corals were held in the dark (darkadapted) for $30 \mathrm{~min}$ prior to fluorescence measurements (Jones \& Hoegh-Guldberg 2001). During measurements, the fibre-optic light guide was held $<2 \mathrm{~mm}$ from the coral, $2 \mathrm{~cm}$ from the tip on a vertical plane. Initial fluorescence $\left(F_{0}\right)$ was measured by applying a weak pulse of red light $\left(<1 \mu \mathrm{mol}\right.$ quanta $\left.\mathrm{m}^{-2} \mathrm{~s}^{-1} \mathrm{PAR}\right)$. A saturating pulse $\left(8000 \mu \mathrm{mol}\right.$ quanta $\mathrm{m}^{-2} \mathrm{~s}^{-1} ; 800 \mathrm{~ms}$ pulse width) was applied to determine maximal fluorescence $\left(F_{\mathrm{m}}\right)$. Variable fluorescence $\left(F_{\mathrm{v}}\right)$ was calculated as $F_{\mathrm{m}}-F_{0}$ and maximal potential quantum yield as $F_{\mathrm{v}} / F_{\mathrm{m}}$. During all experiments, chlorophyll fluorescence parameters were measured prior to and at the completion of treatments. Where corals were left for an observation period in the holding/observation tank, fluorescence measurements were made at dawn (06:00 h) and dusk (18:00 h).

Experimental design. During the experimental sequence, 3 types of controls were used. An initial set of freshly excised branches from the parent colonies (parent colony controls, PC) was frozen immediately after collection. A subset of corals (handling controls, HC) was mounted into plastic containers and maintained in the holding/observation tank over the duration of experiments. A third set of controls, (treatment controls, TC) was exposed to ambient seawater only during the experiments.

Short-term exposure experiments. Short-term exposure experiments began at dawn $(06: 00 \mathrm{~h})$ and finished after $12 \mathrm{~h}$. Following treatments, corals were returned to the holding/observation tank and allowed to recover in ambient salinity for 6 to $11 \mathrm{~d}$ before being sacrificed for biomass determination. Chlorophyll fluorescence parameters were measured twice daily during the exposure and recovery periods.

Short-term Expt 1: To determine the response of Stylophora pistillata to a wide range of low-salinity seawater, coral explants were exposed to ambient seawater $(37 \mathrm{ppt}$ ) or reduced-salinity seawater (33.5 to $15 \mathrm{ppt}$ ). Four explants were exposed to each of 7 salinities for $12 \mathrm{~h}$. Following exposure, corals were returned to the holding/observation tank for a $6 \mathrm{~d}$ observation period before being sacrificed.

Short-term Expt 2: The above experiment was repeated with 3 low-salinity treatments $(31.5,26$, $20.5 \mathrm{ppt}$ ) and ambient salinity (37 ppt) in 3 replicate tanks with 3 corals per tank. 
Light-interaction experiment: To determine whether the effect of reduced salinity on Stylophora pistillata is light-dependent, corals were exposed to either ambient seawater (37 ppt) or reduced-salinity seawater (20.5 ppt) in near darkness or light for $12 \mathrm{~h}$. 'Light' treatments were exposed to natural light conditions whilst 'dark' treatments were covered by black plastic that reduced light levels to $<10 \mu \mathrm{mol}$ quanta $\mathrm{m}^{-2} \mathrm{~s}^{-1}$. Corals were sacrificed $10 \mathrm{~d}$ after return to the holding/observation tank.

Long-term exposure experiment. To examine the chronic (longer-term) response to low-salinity stress, Stylophora pistillata was exposed to ambient seawater (37 ppt) or reduced-salinity seawater $(33.5,29.5$, $26 \mathrm{ppt}$ ) for $12 \mathrm{~d}$. Three replicate tanks with 3 corals per tank were used for each treatment. The salinity in each tank was monitored daily and freshwater added if the salinity had risen due to evaporation and replaced every $3 \mathrm{~d}$ to prevent stagnation. Salinities did not vary more than $1 \mathrm{ppt}$ over the exposure period. Chlorophyll fluorescence parameters were measured twice daily, and after $12 \mathrm{~d}$ exposure corals were sacrificed for biomass determination.

Time-course experiment. The response of Stylophora pistillata to exposure to very low salinity (10 ppt) was investigated over a 5 to $120 \mathrm{~min}$ period. Tests were conducted over the time of peak irradiance, from 11:00 h until 13:00 h. Nine 21 aquaria were filled with seawater diluted to $10 \mathrm{ppt}$ and 5 corals placed into each. One coral was removed from each aquarium after 5, 10, 30, 60 and 120 min exposure and returned to the holding/observation tank. Three $2 \mathrm{l}$ aquaria served as controls and were filled with ambient seawater. Three corals were placed into each of these tanks and returned to the holding/observation tank after $120 \mathrm{~min}$. All corals were held for a $7 \mathrm{~d}$ observation period before being sacrificed for biomass determination. Chlorophyll fluorescence parameters were measured before and after exposure and throughout the observation period.

Dinoflagellate density determination. Tissue was stripped from coral skeletons with a jet of recirculating seawater using a Water-Pik ${ }^{\mathrm{TM}}$ (Johannes \& Wiebe 1970). Subsamples of the homogenate were taken and the density of symbiotic dinoflagellates determined from 8 replicate counts using a hemacytometer. Chl a concentration in three $13.5 \mathrm{ml}$ subsamples was determined according to the equations of Jeffrey \& Humphrey (1975). Total symbiotic dinoflagellates and chl a were determined after correction for the total homogenate volume and are expressed per unit surface area. Surface area was determined by the paraffin wax technique (Stimson \& Kinzie 1991). Techniques are fully described in Jones et al. (2000).

Data analysis. All data are presented as the mean $(\bar{X})$ $\pm 95 \%$ confidence intervals. Treatments were com- pared using 1-way ANOVAs. In all instances (except the time-course experiment) there was no significant difference between field, handling and treatment controls $(\mathrm{p}<0.001)$ and thus, experimental values are compared to treatment controls (TC).

\section{RESULTS}

\section{Salinity tolerance}

Stylophora pistillata fragments were dead $1 \mathrm{~d}$ after exposure to salinity levels of $15 \mathrm{ppt}$ for $12 \mathrm{~h}$ and $10 \mathrm{ppt}$ for $120 \mathrm{~min}$. Mortality occurred as tissues sloughed away from the coral skeleton. Corals exposed to salinity ranging from 26 to $18 \mathrm{ppt}$ for $12 \mathrm{~h}$ or $12 \mathrm{~d}$ and $10 \mathrm{ppt}$ for 10 to $60 \mathrm{~min}$ remained alive but discoloured within $3 \mathrm{~d}$ of exposure to the low salinity. During the exposure and observation periods, the polyps of corals (which eventually discoloured) remained fully extended and responded to tactile stimulation by contracting into their calices.

\section{Chlorophyll fluorescence}

In affected corals, chlorophyll fluorescence measurements of dark-adapted $F_{\mathrm{v}} / F_{\mathrm{m}}$ followed a general pattern of an initial rapid decrease followed by a more gradual increase to levels within 5 to $10 \%$ of both control and pre-treatment values. Corals from all $12 \mathrm{~h}$ treatments that were exposed to $26 \mathrm{ppt}$ or less displayed an initial reduction of up to $50 \%$ in $F_{\mathrm{v}} / F_{\mathrm{m}}$ over the $12 \mathrm{~h}$ exposure period. This decreased further overnight and reached the lowest value $12 \mathrm{~h}$ after a return to ambient salinity. The greatest reduction in dark-adapted $F_{\mathrm{v}} / F_{\mathrm{m}}$ was in corals exposed to $18 \mathrm{ppt}$ (65\% reduction, Fig. 1A). Following the initial rapid decline, $F_{\mathrm{v}} / F_{\mathrm{m}}$ gradually increased over the recovery/ observation period and was within $5 \%$ of pre-exposure and control levels by Day 5 (Figs. 1A, 2 \& 3). Corals exposed to $10 \mathrm{ppt}$ for 30 and $60 \mathrm{~min}$ followed the same pattern of decrease and recovery of dark-adapted $F_{\mathrm{v}} / F_{\mathrm{m}}$ as the $12 \mathrm{~h}$ treatment corals (Fig. 4).

Corals exposed to low-salinity seawater for $12 \mathrm{~d}$ also experienced a sudden decrease in dark-adapted $F_{\mathrm{v}} / F_{\mathrm{m}}$ over the first $36 \mathrm{~h}$ of exposure. $F_{\mathrm{v}} / F_{\mathrm{m}}$ in corals exposed to 26 ppt was 0.48 , while corals exposed to 29.5 and 33.5 ppt had no change in fluorescence parameters. $F_{\mathrm{v}} / F_{\mathrm{m}}$ gradually increased to within $10 \%$ of control values by Day 5 and remained at this level for the duration of the $12 \mathrm{~d}$ treatment (Fig. 5).

Dark-adapted $F_{\mathrm{v}} / F_{\mathrm{m}}$ decreased in all corals exposed to salinity of $26 \mathrm{ppt}$ or lower and to $10 \mathrm{ppt}$ for 30 to $120 \mathrm{~min}$ and differences were significant when com- 

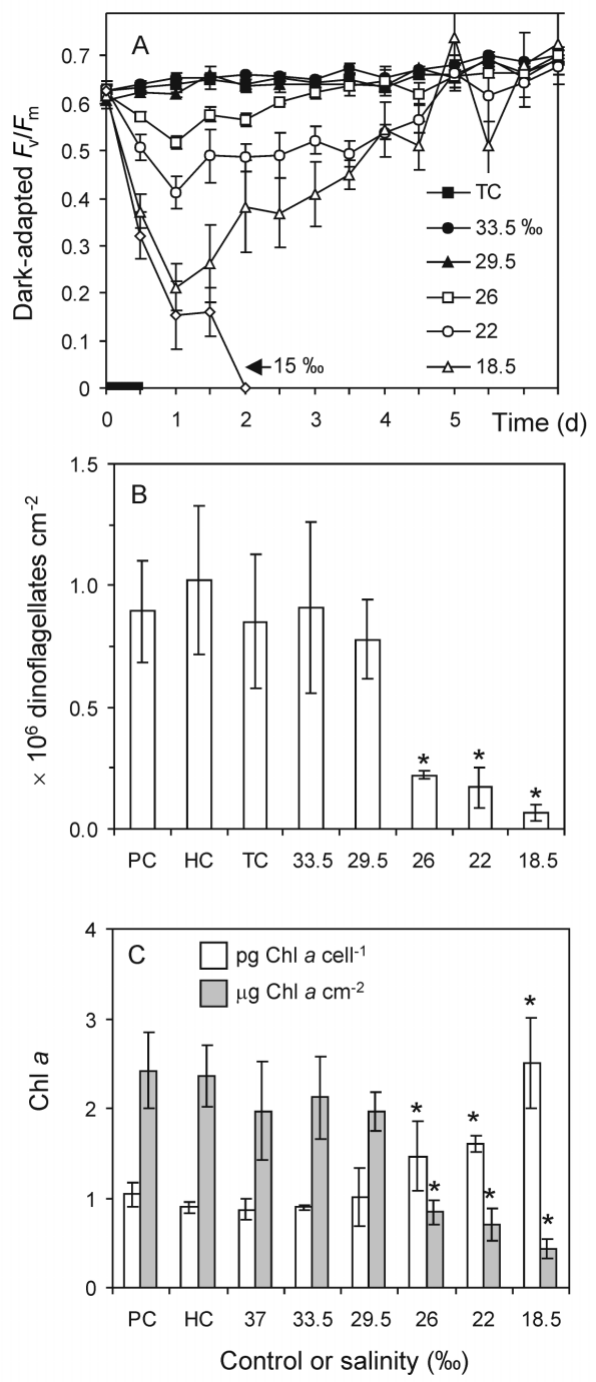

Fig. 1. Stylophora pistillata. (A) Mean dark-adapted $F_{\mathrm{v}} / F_{\mathrm{m}}$ of symbiotic dinoflagellates in coral exposed to salinity levels of 37 to $15 \mathrm{ppt}$ for $12 \mathrm{~h}$ and during a $6 \mathrm{~d}$ observation period (in ambient seawater). The horizontal bar above the $x$-axis represents the exposure period. (B) symbiotic dinoflagellate density $\left(\times 10^{6} \mathrm{~cm}^{-2}\right)$. (C) Chlorophyll a (pg algal cell $\left.{ }^{-1}\right)$ and $\mu \mathrm{g}$ $\mathrm{cm}^{-2}$ ) in coral $6 \mathrm{~d}$ after exposure to salinity levels of 37 (TC) to $18.5 \mathrm{ppt}$ for $12 \mathrm{~h} . \mathrm{PC}=$ parent colony controls, $\mathrm{HC}=$ handling controls and TC $=100 \%$ (ambient) seawater controls. All data are $\pm 95 \% \mathrm{CI}, \mathrm{n}=4$. Asterisks denote significant $(\mathrm{p}<0.001$,

ANOVA) differences from treatment controls TC

pared to TC corals (ANOVA, $\mathrm{p}<0.001, \mathrm{n}=9$ ). Minimum values of $F_{\mathrm{v}} / F_{\mathrm{m}}$ were reached $24 \mathrm{~h}$ after the commencement of experiments (Figs. 2 to 5 ). In short-term Expt $2, F_{\mathrm{v}} / F_{\mathrm{m}}$ in corals exposed to 20.5 ppt was $25 \%$ lower than control values. The $24 \mathrm{~h}$ period over which this decrease occurred included $12 \mathrm{~h}$ at reduced salinity, which was followed by $12 \mathrm{~h}$ at ambient salinity. The minimum dark-adapted $F_{\mathrm{v}} / F_{\mathrm{m}}$ in corals from the longterm experiment was also $25 \%$ lower than control

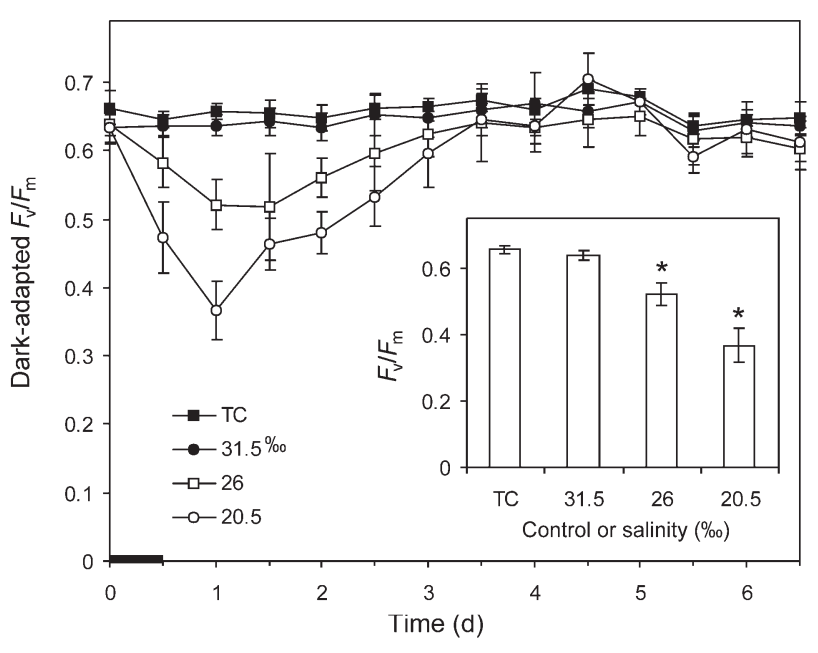

Fig. 2. Stylophora pistillata. Mean dark-adapted $F_{\mathrm{v}} / F_{\mathrm{m}}$ of symbiotic dinoflagellates in coral exposed to salinity levels of 37 $31.5,26$ or $20.5 \mathrm{ppt}$ for $12 \mathrm{~h}$ and during a $6 \mathrm{~d}$ observation period (in ambient seawater). The horizontal bar above the $X$-axis represents the exposure period. Inset: lowest recorded dark-adapted $F_{\mathrm{v}} / F_{\mathrm{m}}$ (after $12 \mathrm{~h}$ observation). All data are $\pm 95 \% \mathrm{CI}, \mathrm{n}=9$. Asterisks denote significant $(\mathrm{p}<0.001$, ANOVA) differences from treatment controls (TC) exposed to ambient seawater

corals, however the experimental corals were maintained at $26 \mathrm{ppt}$ for the entire exposure period. $F_{\mathrm{v}} / F_{\mathrm{m}}$ in corals exposed to $20.5 \mathrm{ppt}$ in full sunlight was lower $(0.38)$ than in corals exposed to low salinity in darkness $(0.48) 12 \mathrm{~h}$ after a return to ambient salinity (Fig. 3). $F_{\mathrm{v}} / F_{\mathrm{m}}$ from both treatments was significantly different from controls (ANOVA, $\mathrm{p}<0.001, \mathrm{n}=9$ ). After $12 \mathrm{~h}$ at ambient salinity, dark-adapted $F_{\mathrm{v}} / F_{\mathrm{m}}$ in corals exposed to $10 \mathrm{ppt}$ for $30 \mathrm{~min}$ was $55 \%$ less than control values and $70 \%$ less than control values in corals exposed for $60 \mathrm{~min}$.

\section{Dinoflagellate density}

At the end of experiments, Stylophora pistillata exposed to salinity of $26 \mathrm{ppt}$ or less had fewer symbiotic dinoflagellates remaining in hospite than control corals. The differences in dinoflagellate density in these corals were significant when compared to control corals (ANOVA, $p<0.001, n=4$ or $n=9$, Figs. 1B \& 6A to $\mathrm{C}$ ). Exposure to $20.5 \mathrm{ppt}$ for $12 \mathrm{~h}$ resulted in a loss of $\sim 80 \%$ of dinoflagellates from coral tissues (Fig. $6 \mathrm{~A}, \mathrm{~B}$ ). Exposure to $26 \mathrm{ppt}$ for $12 \mathrm{~h}$ resulted in a $50 \%$ loss of dinoflagellates, while exposure to the same salinity for $12 \mathrm{~d}$ resulted in a $90 \%$ decrease (compare Fig. 6A with Fig. 6C). Corals exposed to $10 \mathrm{ppt}$ for 10 to $60 \mathrm{~min}$ also lost up to $90 \%$ of symbiotic dinoflagellates. Dinoflagellate density in these corals was significantly different 


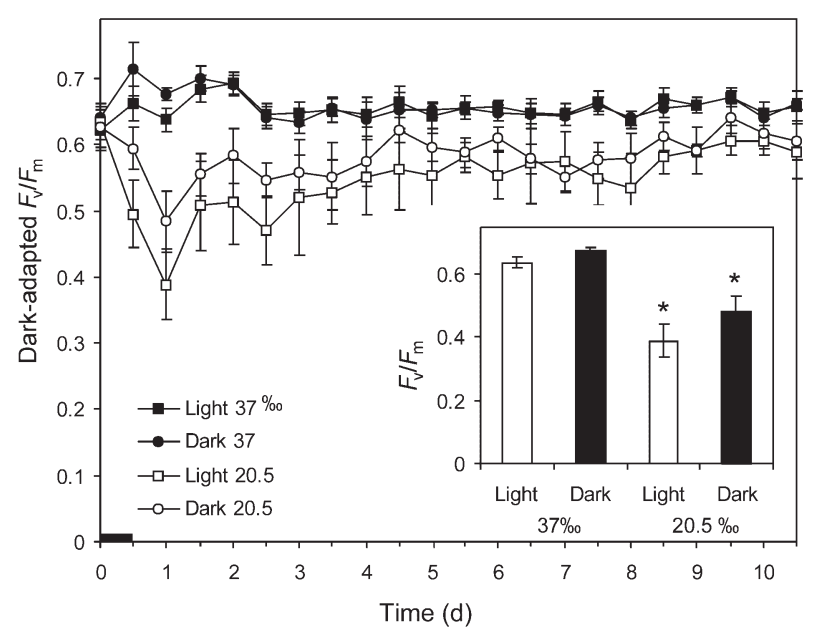

Fig. 3. Stylophora pistillata. Mean dark-adapted $F_{\mathrm{v}} / F_{\mathrm{m}}$ of symbiotic dinoflagellates in coral exposed to salinity levels of $37 \mathrm{ppt}$ (TC) or $20.5 \mathrm{ppt}$ for $12 \mathrm{~h}$ in near darkness or under natural daylight and during a $10 \mathrm{~d}$ observation period (in ambient seawater). The horizontal bar above the $x$-axis represents the exposure period. Inset: lowest recorded dark-adapted $F_{\mathrm{v}} / F_{\mathrm{m}}$ (after $12 \mathrm{~h}$ observation). All data are $\pm 95 \% \mathrm{CI}, \mathrm{n}=9$. Asterisks denote significant ( $p<0.001$, ANOVA) differences from treatment controls (TC) exposed to ambient seawater

from control corals (ANOVA, $\mathrm{p}<0.001, \mathrm{n}=9$, Fig. 6D). In all experiments, corals which experienced a decline in dark-adapted $F_{\mathrm{v}} / F_{\mathrm{m}}$ after $24 \mathrm{~h}$ also lost significant proportions of symbiotic dinoflagellates (compare Figs. 2-5 with 6A-D).

Chl a concentrations were determined for corals in short-term Expt 1. Corals which lost symbiotic dinoflagellates also experienced a $50 \%$ reduction in areal chl a concentration. However, symbiotic dinoflagellates in remaining in host tissues had chl a concentrations of between 1.5 and $2.5 \mathrm{pg}$ cell $^{-1}$, which was approximately 2 to 3 times the concentration of chl $a$ in cells from corals with unchanged dinoflagellate density (Fig. 1C). Differences in chl a concentrations were significant when compared to control values (ANOVA, $\mathrm{p}<0.001, \mathrm{n}=4)$.

\section{DISCUSSION}

The most obvious physiological response of Stylophora pistillata to exposure to reduced-salinity seawater was a discolouration of the coral tissues. This discolouration was, in most instances, a sublethal response and involved a loss of the endosymbiotic dinoflagellate microalgae, thus conforming to current definitions of coral bleaching (see Fitt et al. 2001). Recently, it has been suggested that the discolouration of corals following osmotic stress is not caused by the

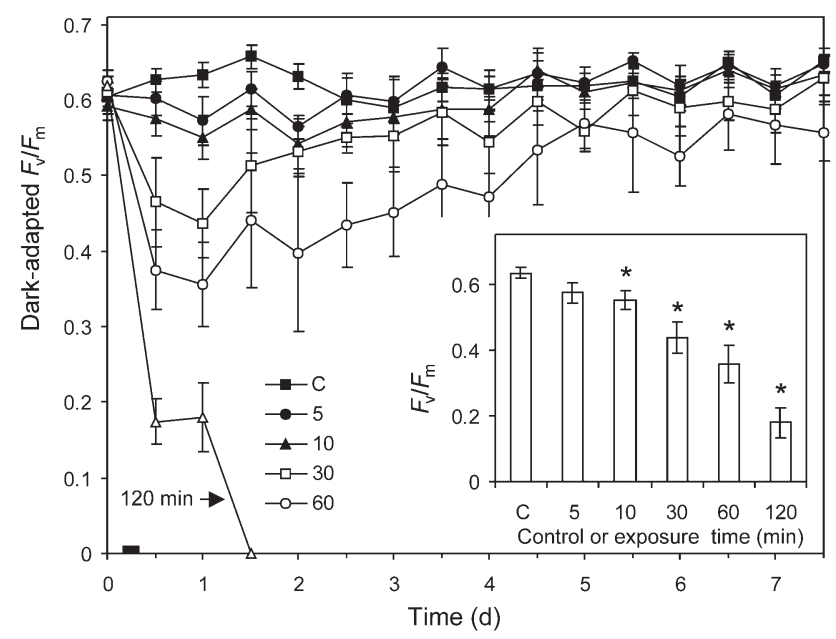

Fig. 4. Stylophora pistillata. Mean dark-adapted $F_{\mathrm{v}} / F_{\mathrm{m}}$ of symbiotic dinoflagellates in coral exposed to a salinity level of $10 \mathrm{ppt}$ for 5 to $120 \mathrm{~min}$ or to $37 \mathrm{ppt}$ for $120 \mathrm{~min}$ (control, C) and during a $7 \mathrm{~d}$ observation period (in ambient seawater). The horizontal bar above the $x$-axis represents the exposure period. Inset: lowest recorded dark-adapted $F_{\mathrm{v}} / F_{\mathrm{m}}($ after $12 \mathrm{~h}$ observation). All data are $\pm 95 \% \mathrm{CI}, \mathrm{n}=9$. Asterisks denote significant $(\mathrm{p}<0.001$, ANOVA) differences from controls $(\mathrm{C})$ exposed to ambient seawater

dissociation of the coral-algal symbiosis (bleaching), but rather by death of the coral (Hoegh-Guldberg 1999). However, the results of this study refute HoeghGuldberg's (1999) suggestion. A loss of symbiotic dinoflagellates occurred in S. pistillata subjected to both dramatic decreases in salinity for short periods (i.e. min to $\mathrm{h}$ ) and slight decreases in salinity for long periods (i.e. d). Mortality and sloughing of the tissues from the skeleton was observed, but only in corals exposed to extremely low-salinity seawater. In these instances, all that remained was a bare, white coral skeleton which very superficially resembled a heavily bleached coral. However, in the treatments where bleaching occurred, it was via a loss of symbiotic dinoflagellates from the tissues of the corals, which were otherwise alive and responding to tactile stimuli. Thus bleaching, or the dissociation of the coral-algal symbiosis, was a quantifiable sublethal response to hypo-osmotic stress.

In response to reduced-salinity seawater, bleaching occurred through a loss of symbiotic dinoflagellates from coral tissues, which resulted in a reduction in areal chl a concentration. However, the concentration of chl a per algal cell remaining inside bleached corals increased to twice that of normally pigmented (control) corals. Many other studies have reported higher chl a concentrations per algal cell in corals recovering from bleaching events (Fitt et al. 1993, Le Tissier \& Brown 1996, Jones 1997, Brown et al. 1999b), although earlier studies have indicated lower algal chl a concentrations 


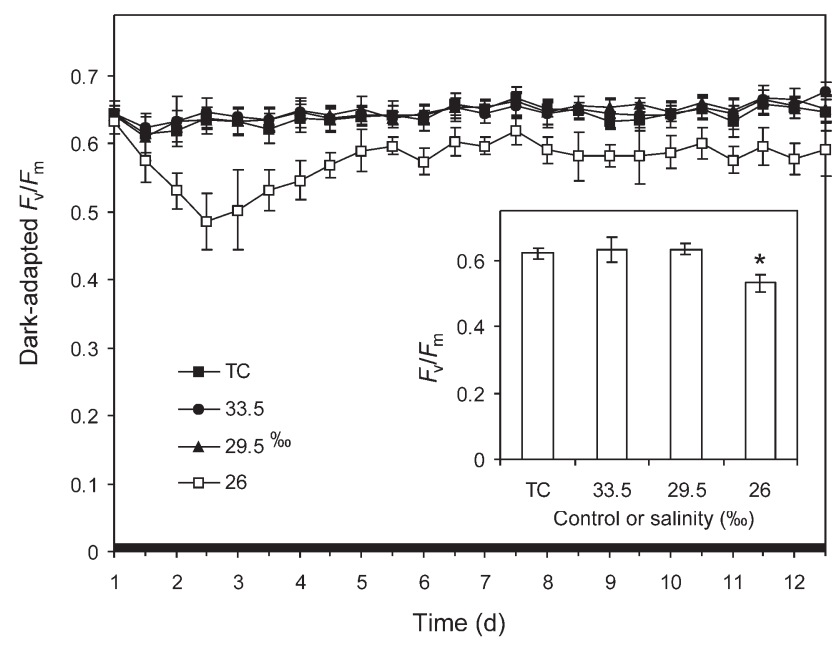

Fig. 5. Stylophora pistillata. Mean dark-adapted $F_{\mathrm{v}} / F_{\mathrm{m}}$ of symbiotic dinoflagellates in coral exposed to salinity levels of 37 , $33.5,29.5$ or $26 \mathrm{ppt}$ for $12 \mathrm{~d}$. The horizontal bar above the $x$-axis represents the exposure period. Inset: lowest recorded darkadapted $F_{\mathrm{v}} / F_{\mathrm{m}}$ (after $36 \mathrm{~h}$ exposure). All data are $\pm 95 \% \mathrm{CI}, \mathrm{n}=$ 9. Asterisks denote significant $(\mathrm{p}<0.001$, ANOVA) differences from treatment controls (TC) exposed to ambient seawater
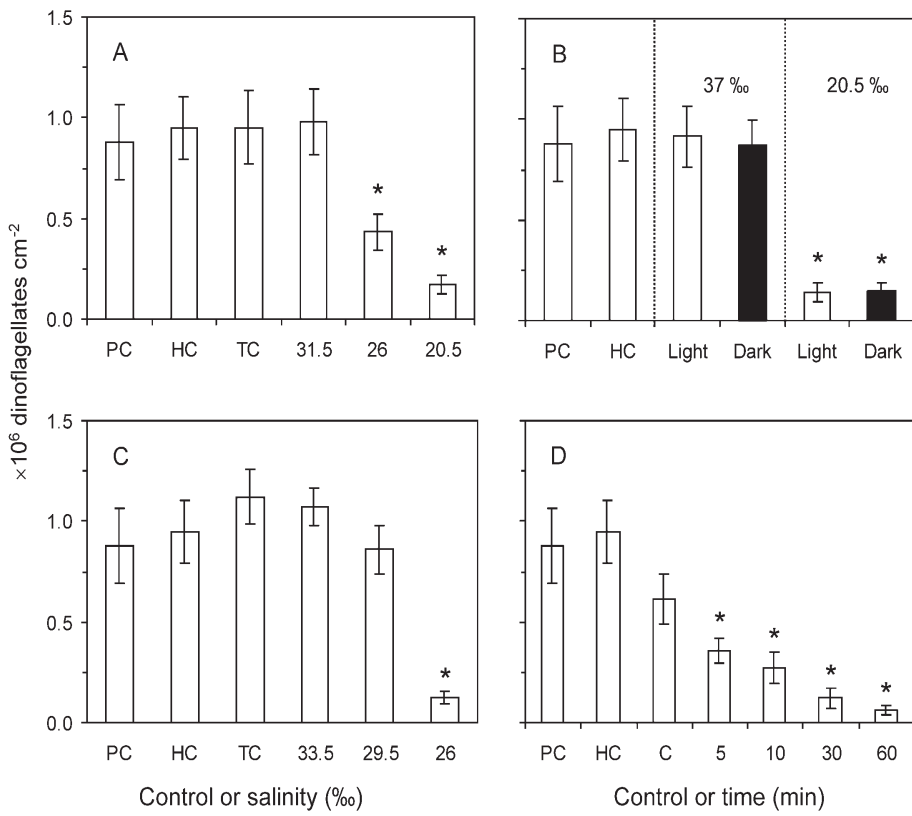

Fig. 6. Stylophora pistillata. Symbiotic dinoflagellate density $\left(\times 10^{6}\right.$ dinoflagellates $\mathrm{cm}^{-2}$ ) in coral (A) $6 \mathrm{~d}$ after exposure to a salinity level of $37 \mathrm{ppt}$ (TC) or seawater diluted to $31.5,26$ or 20.5 ppt for $12 \mathrm{~h}_{\text {; }}$ (B) $10 \mathrm{~d}$ after exposure to $37 \mathrm{ppt}$ (TC) or $20.5 \mathrm{ppt}$ in near darkness or under natural daylight for $12 \mathrm{~h}_{\text {; }}(\mathrm{C})$ after $12 \mathrm{~d}$ exposure to $37 \mathrm{ppt}$ or seawater diluted to $33.5,29.5$ or $26 \mathrm{ppt}_{\text {; }}$ (D) $7 \mathrm{~d}$ after exposure to $10 \mathrm{ppt}$ for 5 to $60 \mathrm{~min}$ or $37 \mathrm{ppt}$ for $120 \mathrm{~min}$. $\mathrm{PC}=$ parent colony controls, $\mathrm{HC}=$ handling control, $\mathrm{TC}=$ ambient seawater controls and $\mathrm{C}=$ control $(120 \mathrm{~min}$ exposure to ambient seawater). All data are $\pm 95 \% \mathrm{CI}, \mathrm{n}=9$. Asterisks denote significant $(\mathrm{p}<0.001$, ANOVA) differences from treatment controls (TC)
(Kleppel et al. 1989). Why chl a concentrations are higher in algae remaining in the coral tissues following bleaching is presently unclear (see Le Tissier \& Brown 1996, Jones 1997). However, it is clear that any attempt to define coral bleaching by reference to the chlorophyll content of the algae will quickly become confused when (1) corals with fewer symbionts have higher chl a cell ${ }^{-1}$ concentrations than control corals and (2) this trend is not consistent across all studies.

In this study, chlorophyll fluorescence techniques were used to assess the photosynthetic capacity of algal symbionts in hospite. In some cases, exposure to low-salinity seawater caused a marked long-term reduction in the PSII efficiency, assessed as the ratio of variable to maximal fluorescence in a dark-adapted sample $\left(F_{\mathrm{v}} / F_{\mathrm{m}}\right)$. This was measured in Stylophora pistillata exposed to a range of low-salinity treatments over the short-term (min to h) and long-term (d). Reductions in the rate of photosynthesis, measured as a decrease in oxygen evolution, have also been documented in several coral species exposed to low salinity over similar timescales (Muthiga \& Szmant 1987, Moberg et al. 1997, Ferrier-Pages et al. 1999, Alutoin et al. 2001). Both behavioural and physiological responses have been proposed to account for these changes. Several studies suggest that the retraction of animal tissues into the skeleton, thereby preventing excessive water uptake, may restrict gas exchange and reduce the light levels experienced by the dinoflagellate (Muthiga \& Szmant 1987, Moberg et al. 1997, FerrierPages et al. 1999). Muthiga \& Szmant (1987) suggest changes in photosynthesis are more physiological, involving damage to the algal cell ultrastructure. In seaweeds, hypo-osmotic stress causes increases in cell volume and turgor, which damages membranes and organelles and can culminate in cell rupture (Lobban \& Harrison 1994). Changes in ion concentrations, associated with osmotic fluctuations, may have an inhibitory effect on enzyme systems (Lobban \& Harrison 1994) and many reactions involved in photosynthesis are dependent on enzymatic processes (Falkowski \& Raven 1997).

There was an apparent link between a reduction in the dark-adapted $F_{\mathrm{v}} / F_{\mathrm{m}}$ of symbiotic dinoflagellates in hospite during the experiments and the subsequent loss of symbionts measured at the end of the observation period. Decreases in dark-adapted $F_{\mathrm{v}} / F_{\mathrm{m}}$ in corals exposed to low salinity preceded the loss of symbiotic dinoflagellates from coral tissues across all experiments. Within each experiment, corals that experienced the largest reduction in dark-adapted $F_{\mathrm{v}} / F_{\mathrm{m}}$ lost the most symbiotic dinoflagellates. It is particularly noticeable that corals exposed to $29.5 \mathrm{ppt}$ seawater for $12 \mathrm{~h}$ and $12 \mathrm{~d}$ did not suffer a decrease in $F_{\mathrm{v}} / F_{\mathrm{m}}$ and suffered no subsequent loss of algae; however, in 
corals exposed to a few ppt less (i.e. 26 ppt) darkadapted $F_{\mathrm{v}} / F_{\mathrm{m}}$ was reduced and a significant loss of algae occurred. The corals exposed to 29.5 ppt were likely to have become iso-osmotic to the surrounding seawater within minutes of exposure (Engebretson \& Martin 1994).

An impairment of algal photosynthesis (measured as a long-term decrease in dark-adapted $F_{\mathrm{v}} / F_{\mathrm{m}}$ ) and loss of algal symbionts has been observed in corals following exposure to many stressors. These include heat stress (Fitt \& Warner 1995, Warner et al. 1996, Jones et al. 1998), cold stress (Saxby 2001), cyanide ions (Jones \& Hoegh-Guldberg 1999) and elevated light levels (Jones \& Hoegh-Guldberg 2001), as well as elevated copper and effluents from the offshore oil and gas industry (R. J. Jones unpubl. data). Reductions in darkadapted $F_{\mathrm{v}} / F_{\mathrm{m}}$ in these studies have typically been discussed in terms of photoinhibition, the light-dependent inhibition of the light reactions of photosynthesis (Long et al. 1994, Osmond 1994). In this study, decreases in dark-adapted $F_{\mathrm{v}} / F_{\mathrm{m}}$ also occurred in corals exposed to reduced-salinity seawater $(20.5 \mathrm{pt})$ in darkness. The reduction in photochemical efficiency of the algae seen in corals exposed to low salinity cannot, therefore, be attributed to photoinhibitory processes alone, as photoinhibition is, by definition, a light-dependent process (Long et al. 1994, Osmond 1994).

Earlier examinations of the response of corals to lowsalinity seawater suggested that the cause of bleaching was primarily associated with the host while the algal symbionts played a more passive role in bleaching (Van Woesik et al. 1995). Bleaching was interpreted as being caused by the swelling and perhaps rupture of host cells (Van Woesik et al. 1995). The results from this study, although correlative, suggest that the algae are not passively lost from the coral during hypoosmosis: the dissociation of the coral-algal symbiosis only occurred when there was a reduction in the PSII efficiency measured in hospite. However, this does not preclude some effect of reduced salinity on the animal host cells.

\section{Management implications}

This study demonstrates how exposure to low-salinity seawater alone can cause some of the symptoms commonly attributed to temperature anomalies and anthropogenic pressures on coral reefs. It was found that decreases in the photochemical efficiency of the algal symbionts, as well as bleaching, can simply be caused by osmotic effects. These results highlight the difficulty of differentiating between the effects of warm water, herbicide-contaminated water and reduced-salinity seawater on corals when exposure is simultaneous. Contamination of the Great Barrier Reef Marine Park with PSII inhibiting herbicides has recently been reported (Haynes et al. 2000). These herbicides, which may enter the marine environment in river runoff associated with floods, also cause decreases in $F_{\mathrm{v}} / F_{\mathrm{m}}$ and bleaching in corals (Jones et al. 2003). On the Great Barrier Reef, heavy rain associated with monsoons, tropical depressions and cyclones occur during the summer months when maximum seawater temperatures also occur. The bleaching of reefs around Magnetic Island during the 1998 Great Barrier Reef mass-bleaching event also coincided with heavy rainfall and a reduction in surface salinity levels to $<30 \mathrm{ppt}$ for several weeks (Berkelmans \& Oliver 1999). Questions remain as to whether the bleaching of corals occurred because of the low-salinity seawater or elevated temperatures, or both (Berkelmans \& Oliver 1999). The power of PAM chlorophyll fluorescence techniques lies in the ability to rapidly assess the passage of a stress factor(s) over coral reefs and, due to the apparent link between a decrease in $F_{\mathrm{v}} / F_{\mathrm{m}}$ and loss of dinoflagellates, predict if coral bleaching may occur.

This study has established that the discolouration of corals commonly observed after contact with lowsalinity seawater is due to a loss of symbiotic dinoflagellates from host tissues and not coral death as recently suggested. The use of PAM fluorometry has revealed that an impairment of algal photosynthesis precedes the loss of dinoflagellates from hypoosmotically stressed corals. Reasons for the impairment of algal photosynthesis may include damage to cellular structures and/or enzymatic systems within symbiotic dinoflagellates exposed to low-salinity seawater. The implications of these results are important when considering that corals may experience salinity stress in combination with other factors such as elevated water temperature and pollutants from coastal runoff. Thus, the effects of low salinity on corals and coral reefs must be considered in the wider context of both mass bleaching and increasing anthropogenic stressors.

Acknowledgements. The authors would like to acknowledge the staff of Heron Island Research Station. This study was supported by an Australian Research Council (ARC) Strategic Partnership with Industry (SPIRT) award and by the Great Barrier Reef Marine Parks Authority (GBRMPA).

\section{LITERATURE CITED}

Alutoin S, Boberg J, Nystrom M, Tedengren M (2001) Effects of multiple stressors copper and reduced salinity on the metabolism of the hermatypic coral Porties lutea. Mar Environ Res 52:289-299

Berkelmans R, Oliver JK (1999) Large-scale bleaching of corals on the Great Barrier Reef. Coral Reefs 18:55-60

Brown BE, Ambarsari I, Warner ME, Fitt WK, Dunne RP, Gibb 
SW, Cummings DG (1999a) Diurnal changes in photochemical efficiency and xanthophyll concentrations in shallow water reef corals: evidence for photoinhibition and photoprotection. Coral Reefs 18:99-105

Brown BE, Dunne RP, Ambarsari I, Le Tissier MDA, Satapoomin U (1999b) Seasonal fluctuations in environmental factors and variations in symbiotic algae and chlorophyll pigments in four Indo-Pacific coral species. Mar Ecol Prog Ser 191:53-69

Cloud PE (1952) Preliminary report on geology and marine environments of Onotoa Atoll, Gilbert Islands. Atoll Res Bull 12:1-73

Coles SL (1992) Experimental comparison of salinity tolerances of reef corals from the Arabian Gulf and Hawaii: evidence for hyperhaline adaptation. Proc 7th Int Coral Reef Symp, Guam, 1:227-234

Coles SL, Jokiel PL (1992). Effects of salinity on coral reefs. In: Connell DW, Hawker DW (eds) Pollution in tropical aquatic systems. CRC Press, Boca Raton, FL, p 147-166

Devlin M, Taylor J, Brodie J (1998) Flood plumes, extent, concentration and composition. GBRMPA Reef Res 8:1-9

Egana AC, DiSalvo LH (1982) Mass expulsion of zooxanthellae by Easter Island corals. Pac Sci 36:61-63

Engebretson H, Martin KLM (1994) Effects of decreased salinity on expulsion of zooxanthellae in the symbiotic sea anemone Anthopleura elegantissima. Pac Sci 48:446-457

Falkowski PG, Raven JA (1997) Aquatic photosynthesis. Blackwell Science, Malden, MA

Ferrier-Pages C, Gattuso JP, Jaubert J (1999) Effect of small variations in salinity on the rates of photosynthesis and respiration of the zooxanthellate coral Stylophora pistillata. Mar Ecol Prog Ser 181:309-314

Fitt WK, Warner ME (1995) Bleaching patterns of four species of Caribbean reef corals. Biol Bull 189:298-307

Fitt WK, Spero HJ, Halas J, White MW, Porter JW (1993) Recovery of the coral Montastrea annularis in the Florida Keys after the 1987 Caribbean 'bleaching event'. Coral Reefs 12:57-64

Fitt WK, Brown BE, Warner ME, Dunne RP (2001) Coral bleaching: interpretation of thermal tolerance limits and thermal thresholds in tropical corals. Coral Reefs 20:51-65

Glynn PW (1991) Coral reef bleaching in the 1980s and possible connections with global warming. Trend Ecol Evol 6: 175-179

Goodbody I (1961) Mass mortality of a marine fauna following tropical rains. Ecology 42:150-155

Goreau TF (1964) Mass expulsion of zooxanthellae from Jamaican reef communities after Hurricane Flora. Science 145:383-386

Haynes D, Muller J, Carter S (2000a) Pesticide and herbicide residues in sediments and seagrasses from the Great Barrier Reef world heritage area and Queensland coast. Mar Pollut Bull 41:279-287

Hoegh-Guldberg O (1999) Climate change, coral bleaching and the future of the world's coral reefs. Mar Freshw Res 50:839-866

Hoegh-Guldberg O, Jones RJ (1999) Photoinhibition and photoprotection in symbiotic dinoflagellates from reefbuilding corals. Mar Ecol Prog Ser 183:73-86

Iglesias-Prieto R, Matta JL, Robins WA, Trench TR (1992) Photosynthetic response to elevated sea temperature in the symbiotic dinoflagellate Symbiodinium microadriaticum in culture. Proc Natl Acad Sci USA 89:302-305

Jeffrey SW, Humphrey GF (1975) New spectrophotometric equations for determining chlorophylls $a, b, c$ and $c_{2}$ in higher plants, algae and natural phytoplankton. Biochem Physiol Pflanz 167:191-194
Johannes RE, Wiebe WJ (1970) A method for determination of coral tissue biomass and composition. Limnol Oceanogr 21:540-547

Jones RJ (1997) Changes in zooxanthellar densities and chlorophyll concentrations in corals during and after a bleaching event. Mar Ecol Prog Ser 158:51-59

Jones RJ, Hoegh-Guldberg O (1999) Effects of cyanide on coral photosynthesis: implications for identifying the cause of coral bleaching and for assessing the environmental effects of cyanide fishing. Mar Ecol Prog Ser 177:83-91

Jones RJ, Hoegh-Guldberg O (2001) Diurnal changes in the photochemical efficiency of the symbiotic dinoflagellates (Dinophyceae) of corals: photoprotection, photoinactivation and the relationship to coral bleaching. Plant Cell Environ 24:89-99

Jones RJ, Hoegh-Guldberg O, Larkum AWD, Schreiber U (1998) Temperature-induced bleaching of corals begins with impairment of the $\mathrm{CO}_{2}$ fixation mechanism in zooxanthellae. Plant Cell Environ 21:1219-1230

Jones RJ, Kildea T, Hoegh-Guldberg O (1999) PAM chlorophyll fluorometry: a new in situ technique for stress assessment in scleractinian corals, used to examine the effects of cyanide from cyanide fishing. Mar Pollut Bull 38:864-874

Jones RJ, Ward S, Yang Amri A, Hoegh-Guldberg O (2000) Changes in quantum efficiency of Photosystem II of symbiotic dinoflagellates of corals after heat stress, and of bleached corals sampled after the 1998 Great Barrier Reef mass bleaching event. Mar Freshw Res 51:63-71

Jones RJ, Muller J, Haynes D, Schreiber U (2003) Effects of herbicides diuron and atrazine on corals of the Great Barrier Reef, Australia. Mar Ecol Prog Ser 251:153-167

Kleppel GS, Dodge RE, Reese CS (1989) Changes in pigmentation associated with the bleaching of stony corals. Limnol Oceanogr 34:1331-1335

Krause GH, Weis E (1991) Chlorophyll fluorescence and photosynthesis: the basics. Annu Rev Plant Physiol Plant Mol Biol 42:313-349

Le Tissier MDA, Brown BE (1996) Dynamics of solar bleaching in the intertidal reef coral Goniastrea aspera at Ko Phuket, Thailand. Mar Ecol Prog Ser 136:235-244

Lobban CS, Harrison PJ (1994) Seaweed Ecology and Physiology. Cambridge University Press, Cambridge

Long SP, Humphries S, Falkowski PG (1994) Photoinhibition of photosynthesis in nature. Annu Rev Plant Physiol Plant Mol Biol 45:633-663

Marcus J, Thorhaug A (1981) Pacific versus Atlantic responses of the subtropical hermatypic coral Porites spp. to temperature and salinity effects. Proc 4th Int Coral Reef Symp, Quezon City 2:15-20

Moberg F, Nystrom M, Kautsky N, Tedengren M, Jarayabhand P (1997) Effects of reduced salinity on the rates of photosynthesis and respiration in the hermatypic corals Porites lutea and Pocillopora damicornis. Mar Ecol Prog Ser 157:53-59

Muthiga NA, Szmant AM (1987) The effects of salinity stress on the rates of aerobic respiration and photosynthesis in the hermatypic coral Siderastrea siderea. Biol Bull 173:539-551

Orr AP, Moorhouse FW (1933) Variations in physical and chemical conditions on and near Low Isles Reef. Scientific Report of the Great Barrier Reef Expedition, Vol 2 No 4. British Museum (Natural History), London, p 89-98

Osmond CB (1994). What is photoinhibition? Some insights from comparison of shade and sun plants. In: Bake NR, Boyer JR (eds) Photoinhibition: molecular mechanisms to the field. Bios Scientific Publications, Oxford, p 1-24

Rankin JC, Davenport J (1981) Animal osmoregulation. Blackie \& Sons, Glasgow 
Sakami T (2000) Effects of temperature, irradiance, salinity and inorganic nitrogen concentration on coral zooxanthellae in culture. Fish Sci 66:1006-1013

Saxby T (2001) Photosynthetic response of the coral Montipora digitata to cold temperature stress. Honours thesis, The University of Queensland, Brisbane

Schreiber U, Schliwa U, Bilger W (1986) Continuous recordings of photochemical and non-photochemical chlorophyll fluorescence quenching with a new type of modulation flurometry. Photosynth Res 10:51-62

Stimson J, Kinzie RA (1991) The temporal pattern and rate of release of zooxanthellae from the reef coral Pocillopora damicornis (Linnaeus) under nitrogen-enrichment and control conditions. J Exp Mar Biol Ecol 153:63-74

Titlyanov EA, Tsukahara J, Titlyanova TV, Leletkin VA, Van

Editorial responsibility: Tony Underwood (Contributing

Editor), Sydney, Australia
Woesik R, Yamazato K (2000) Zooxanthellae population density and physiological state of the coral Stylophora pistillata during starvation and osmotic shock. Symbiosis 28:303-322

Van Woesik R, De Vantier LM, Glazebrook JS (1995) Effects of Cyclone 'Joy' on nearshore coral communities of the Great Barrier Reef. Mar Ecol Prog Ser 128:261-270

Warner ME, Fitt WK, Schmidt GW (1996) The effects of elevated temperature on the photosynthetic efficiency of zooxanthellae in hospite from four different species of reef coral: a novel approach. Plant Cell Environ 19: 291-299

Warner ME, Fitt WK, Schmidt GW (1999) Damage to Photosystem II in symbiotic dinoflagellates: a determinant of coral bleaching. Proc Natl Acad Sci USA 96:8007-8012

Submitted: May 17, 2002; Accepted: January 8, 2003 Proofs received from author(s): April 24, 2003 